\title{
Study on Sports High School Students' Motivation Levels in Sports by Some Variables
}

\author{
Hüseyin Fatih Kucukibis*,Mehmet Gul \\ School of Physical Education and Sports, Sivas Cumhuriyet University, Turkey
}

Copyright $@ 2019$ by authors, all rights reserved. Authors agree that this article remains permanently open access under the terms of the Creative Commons Attribution License 4.0 International License

\begin{abstract}
The aim of this study is to determine the reasons of motivation of sports high school students and to determine whether these reasons differ according to gender or doing individual sports and team sports. The study included totally 110 sports students who aged between 14 and 18, were doing three individuals sports (table tennis, weight lifting, judo) and three team sports (handball, volleyball, basketball) were subjected to evaluation. The students are 69 male and 41 female individuals. "Sport Motivation Scale” developed by Pelletier et al. (1995) was used as the data collection tool. The Turkish validity and reliability of the scale consisting of 28 items was performed by Kazak (2004). SPSS (Ver.22) package program were used. The data are presented as frequency, percentage (\%), mean and standard deviation. In addition, the normal distribution of data with Kolmogorov Smirnov test was used. Independent Samples t test was used to determine the differences between the variables (individual sport- team sport) with normal distribution. The significance level was accepted as 0.05 in the analyses. In conclusion, it was determined that the reasons of motivation of students who were doing individual sports and team sports depended more on intrinsic motivational factors, and that the order of importance of these factors varied according to the individual sports and team sports variable. It was determined that the reasons of motivation of males and females mainly depended on intrinsic factors and the order of importance of these factors varied according to the gender variable. It can be said that male and female students wanted to get pleasure from the sports they did and to be successful in their sports, thus, they were motivated accordingly.
\end{abstract}

Keywords Sports, Sports High School, Student, Motivation, Sports

\section{Introduction}

Physiological and social motives with various intensities depending on immediate or long-term goals manage the lives of people. Motivation has also been among the issues that sports psychology science has been interested most in recent years. In our daily life, our behaviors take shape and are constantly changing depending on the contents and intensities of the motives. For example, it is only explainable by the power and intensity of motivation considering that there are people running for training in the fields despite negativity and difficulties, when we are too lazy to go to another room (İkizler and Karagözoğlu, 1996). Motivation in a sporting environment can be defined as a desire that drives and directs behavior. Roberts, Treasure and Conroy (2007) explained the motivational process with psychological structures such as directing, organizing and strengthening the behavior of achievement. Hagger and Chatzisarantis (2007) described motivation as the dominant, guiding and empowering behavior process. Alternatively, according to Sage (1984), motivation refers to the direction and intensity of the individual's effort.

There are many factors affecting participation, continuity and performance in sport. Concepts such as games, health, status or performance may be important for individuals in terms of orientation towards sport. Motivation is important in continuity and achievement in sport as well as orientation towards sports (Tiryaki, 2000).

It can be said that motivation is a premise in the emergence of any effort. The direction and intensity of effort are related to motivation. While the direction of the effort refers to approaching or avoiding any situation, the intensity of the effort refers to how much effort is spent in a situation. For example, Ali and Mehmet want to be selected for an "X" football team (the direction of the effort). For this, they both practice four days a week (intensity of effort). When Ali and Mehmet's studies are monitored, it can be said that Ali is more motivated than Mehmet if it is seen that Ali puts more effort in his training than Mehmet does. In addition, it is possible to mention many factors affecting motivation because the individual has to maintain not only his/her organic existence but also his/her social existence. 
Motivation is often misunderstood in the sporting environment. As proof of this, arousal, which is mostly due to competition pressure in the sports environment, is treated as motivation. In other words, low or high arousal is not synonymous with low or high motivation. The encouraging words of the coach or the trainer before the contest starts may increase arousal, but do not increase motivation (Tiryaki, 2000).

In summary, motivation is the state of intrinsic and extrinsic stimulation that directs the individual towards a particular action. Acting in a goal-oriented manner by getting ready via impulse or needs and the feeling of relaxation and pleasure after reaching the goal is called motivation. Motivation is seen as the key element of the achievement for athletes in sports (Gould et al., 2002). In this respect, the studies related to motivation in sports and training can generally be grouped under two objectives. The first is to understand why some people are interested in sports and training and why they do sports, and why others are not interested in doing sports and why they don't do sports. The second objective is what motivation is for achievement, its impact on sports and motivation strategies (Yeltepe, 2007).

The fact that the objective tendencies form the basis of understanding the athlete's motivation, what achievement means for the athlete, and why the athlete acts differently in different environments has led many researchers to investigate the objective tendencies of athletes from different sports fields and how athletes perceive the environment in their respective sports fields. These studies are based on some theories in the field of sports psychology. "Achievement Motivation" and "Achievement Goal" theories are the fundamental theories for the examination of achievement motivation and achievement goals of athletes. In this context, "Achievement Motivation" and "Achievement Goal", which are among the topics frequently discussed in the field of sports psychology, have been examined and explained in the relevant theoretical framework.

\subsection{Achievement Motivation Theory}

Mankind has always been motivated for achievement in school, in business life or in any situation during his or her life, because the need for success or positive emotions that arise after being successful are indispensable for human beings. Achievement motivation is one of the most important issues in the studies related to motivation in the sport environment. Achievement Motivation Theory, which is a frequently used motivation theory in the field of sports and exercise psychology, started with Murray (1983) and was developed by McClelland, Atkinson et al. (1984). While Murray (1983) describes the achievement motivation as an attempt to accomplish a task, overcome obstacles and perform better than others, Gill (1986) defined it as resisting failure, striving to achieve a task and searching for ambiguous situations (cited in Tiryaki, 2000).
Cox (1998) describes the achievement motivation for the sports environment as "the tendency of the athletes to approach and avoid the competition". In general terms, achievement motivation is evaluated as the motivation of the athlete to continue to work, to maintain duty in failure and to have pride in achievement.

\subsection{Achievement Goal Theory}

Motive is one of the main factors that underlie, initiate, and drive human behavior. It is observed that various human behaviors are related to motives. Since the 1970s, sports and exercise psychologists are also interested in what the motives are for starting sports, participating in sports and giving up sports and exercise (Brunstein, 1993; Cresswell et al., 2003; Murcia, Gimeno and Coll, 2008; Toros and Yetim, 2000). Achievement Goal Theory (Achievement Goal Theory), first proposed by Nicholls (1984), is the logical extension of both Bandura's "Self-Efficacy Theory" and Harter's "Proficiency Motivation Theory". Achievement Goal Theory determines the meaning of personal behavior and how individual success and failure are perceived (Singer, Hausenblas ve Janelle, 2001). According to Nicholls (1992), the defined characteristic of achievement motivation is based on the idea that individual perceives his/her own abilities. Nicholls (1992) focused on the goal-oriented nature of achievement behavior and discussed the perception of ability, which is the distinctive quality of achievement motivation. According to this, achievement goals, perceived ability and achievement behaviors are in interaction with determining the motivation of the individual. In this context, in order to understand the motivation of the individual, it is necessary to understand what success and failure means for the individual, how he/she achieves his/her achievement goals and how these goals interact with his/her perception of ability (Weinberg and Gould, 1995).

Motivation is the predictor of any behavior while sports motivation is the predictor of the emergence of sportive behavior. An examination of the motivation levels of high school students who are in the beginning phase of sports will be effective in determining the future existence and quality of sports. The sportive motivation levels of the students studying in the field of sports will be more effective in determining the quality in the sport field. In this sense, it is necessary to examine the motivation of high school students who are studying in sports field.

This study will help to determine the direction of sports education and to understand the reasons of motivation of young people in high school.

\section{Material and Method}

\subsection{Model of the Research}

This research is a descriptive model. A research 
approach in which the opinions and attitudes of the students on certain facts or events are taken and the facts and events are described (Tanrı̈ŏgen, 2011).

\subsection{Research Group}

The population of the research consists of the students studying at the Sports High Schools in the 2018-2019 academic year. The research is limited to the students of the Sports High School. Sports high school students are located at certain quotas according to sports branches. For this reason, a total of 110 athletes participated in the study, 55 of which were individual and 55 of them engaged in team sports.

\subsection{Data Collection Tools}

Sport Motivation Scale (SMS) developed by Pelletier et al. (1995) was used as the data collection tool. The Turkish validity and reliability of the scale consisting of 28 items was performed by Kazak (2004). The scale used in the study is seven likert type. (1- I strongly disagree- 7 I strongly agree). The questions for “amotivation” were not included in the evaluation in order to determine the motivational factors (whether intrinsic or extrinsic) of male and female students who were doing team or individual sports (Table 2, 3, 4, 5). Cronbach alpha coefficient for the SMS scale was determined to be 0.92 .

\subsection{Data Analysis}

SPSS (Ver.22) package program were used. The data are presented as frequency, percentage (\%), mean and standard deviation. In addition, the normal distribution of data with Kolmogorov Smirnov test was used. Independent Samples $\mathrm{t}$ test was used to determine the differences between the variables (individual sport- team sport) with normal distribution. The significance level was accepted as 0.05 in the analyses.

\section{Findings}

The ages of the students included in the study were between 14 and 18, and the age average was found to be $16,69 \mp 1,92$. The distribution percentages according to gender were $37,28 \%$ for 41 female students and $62,72 \%$ for 69 male students.

Upon comparing the subscales in terms of the Sports Motivation Scale (SMS) results of the students, no difference was found between the students who were doing "Individual Sports or Team Sports" for the scores of "to Know - to Accomplish, to Experience Stimulation, Introjection, Identification, and Total Score” $(\mathrm{P}>0,05)$, whereas the difference between the two groups in terms of “Amotivation” was found to be significant $(\mathrm{P}<0,05)$.

Table 1. Independent Groups t Test Results According To Students' Sporting Situation

\begin{tabular}{|c|c|c|c|c|c|}
\hline Status & & $\mathbf{f}$ & $\overline{\mathbf{x}}$ & s.s. & Result \\
\hline \multirow{2}{*}{ To Know - to Accomplish } & Team Sport & 55 & 44,5273 & 8,97704 & \multirow{2}{*}{$\begin{array}{l}\mathrm{t}=1,21 \\
\mathrm{p}=0,227\end{array}$} \\
\hline & Individual Sport & 55 & 42,2727 & 10,43579 & \\
\hline \multirow{2}{*}{ To Experience Stimulation } & Team Sport & 55 & 21,1818 & 4,43091 & \multirow{2}{*}{$\begin{array}{l}t=1,52 \\
p=0,603\end{array}$} \\
\hline & Individual Sport & 55 & 20,6909 & 5,39160 & \\
\hline \multirow{2}{*}{ Extrinsic Motivation } & Team Sport & 55 & 19,3091 & 5,17427 & \multirow{2}{*}{$\begin{array}{l}\mathrm{t}=1,26 \\
\mathrm{p}=0,762\end{array}$} \\
\hline & Individual Sport & 55 & 19,0364 & 5,65018 & \\
\hline \multirow{2}{*}{ Introjection } & Team Sport & 55 & 21,6364 & 5,11122 & \multirow{2}{*}{$\begin{array}{l}\mathrm{t}=1,46 \\
\mathrm{p}=0,146\end{array}$} \\
\hline & Individual Sport & 55 & 20,2000 & 5,17258 & \\
\hline \multirow{2}{*}{ Identification } & Team Sport & 55 & 20,8000 & 4,35635 & \multirow{2}{*}{$\begin{array}{l}\mathrm{t}=1,30 \\
\mathrm{p}=0,195\end{array}$} \\
\hline & Individual Sport & 55 & 19,5455 & 5,65953 & \\
\hline \multirow{2}{*}{ Amotivation } & Team Sport & 55 & 10,4000 & 4,79815 & \multirow{2}{*}{$\begin{array}{l}\mathrm{t}=1,99 \\
\mathrm{p}=0,048 *\end{array}$} \\
\hline & Individual Sport & 55 & 12,4909 & 6,22680 & \\
\hline \multirow{2}{*}{ Total Score } & Team Sport & 55 & 137,8545 & 24,15722 & \multirow{2}{*}{$\begin{array}{l}t=0,700 \\
p=0,484\end{array}$} \\
\hline & Individual Sport & 55 & 134,2364 & 29,64541 & \\
\hline
\end{tabular}


Table 2. Reasons and Motivations of the Students Who Doing Team Sport

\begin{tabular}{|c|c|c|c|c|c|}
\hline Item & Motivational Factor & f & $\overline{\mathbf{x}}$ & s.s. & Dimension \\
\hline 1 & Because I must do sports to feel good about myself. & 55 & 5,92 & 1,35 & Extrinsic \\
\hline 2 & For the pleasure it gives me to know more about the sport that I practice. & 55 & 5,9 & 1,22 & Intrinsic \\
\hline 3 & For the pleasure of discovering new training techniques. & 55 & 5,74 & 1,33 & Intrinsic \\
\hline 4 & For the intense emotions that I feel while I am doing a sport that I like. & 55 & 5,72 & 1,43 & Intrinsic \\
\hline 5 & For the pleasure of discovering new performance strategies. & 55 & 5,7 & 1,62 & Intrinsic \\
\hline 6 & Because it is one of the best ways I have chosen to develop other aspects of myself. & 55 & 5,69 & 1,15 & Extrinsic \\
\hline 7 & For the prestige of being an athlete. & 55 & 5,67 & 1,37 & Extrinsic \\
\hline 8 & $\begin{array}{l}\text { Because it is a good way to learn lots of things which could be useful to me in other areas of my } \\
\text { life. }\end{array}$ & 55 & 5,65 & 1,62 & Extrinsic \\
\hline 9 & Because I must do sports regularly. & 55 & 5,63 & 1,41 & Extrinsic \\
\hline 10 & For the satisfaction I experience while I am perfecting my abilities. & 55 & 5,56 & 1,38 & Intrinsic \\
\hline 11 & For the pleasure that I feel while learning training techniques that I have never tried before. & 55 & 5,49 & 1,56 & Intrinsic \\
\hline 12 & Because I feel a lot of personal satisfaction while mastering certain difficult training techniques. & 55 & 5,43 & 1,46 & Intrinsic \\
\hline 13 & For the excitement I feel when I am really involved in the activity. & 55 & 5,4 & 1,53 & Intrinsic \\
\hline 14 & For the pleasure I feel while improving some of my weak points. & 55 & 5,38 & 1,55 & Intrinsic \\
\hline 15 & For the pleasure I feel while executing certain difficult movements. & 55 & 5,29 & 1,61 & Intrinsic \\
\hline 16 & Because it is absolutely necessary to do sports if one wants to be in shape. & 55 & 5,2 & 1,73 & Extrinsic \\
\hline 17 & For the pleasure I feel in living exciting experiences. & 55 & 5,16 & 1,76 & Intrinsic \\
\hline 18 & Because I would feel bad if I was not taking time to do it. & 55 & 4,89 & 2,04 & Extrinsic \\
\hline 19 & Because I like the feeling of being totally immersed in the activity. & 55 & 4,87 & 1,59 & Intrinsic \\
\hline 20 & Because it is one of the best ways to maintain good relationships with my friends. & 55 & 4,78 & 1,83 & Extrinsic \\
\hline 21 & Because, in my opinion, it is one of the best ways to meet people. & 55 & 4,67 & 1,52 & Extrinsic \\
\hline 22 & To show others how good I am at my sport. & 55 & 4,6 & 1,93 & Extrinsic \\
\hline 23 & Because people around me think it is important to be in shape. & 55 & 4,56 & 1,7 & Extrinsic \\
\hline 24 & Because it allows me to be well regarded by people that I know. & 55 & 4,47 & 1,92 & Extrinsic \\
\hline
\end{tabular}

It was determined that the motivation dimensions of the students doing team sports were mainly related to intrinsic motivation. As for the reasons to do sports, it was primarily important to know more about the sport that one does, to discover new training techniques and to discover new methods to improve performance.
It was determined that the reasons that motivated the students doing team sports the least were maintaining good relations with their friends, sports being the best way to meet people, professionalizing in their sports, being in shape, and being well respected. 
Table 3. Reasons and Motivations of the Students Who Doing Individual Sport

\begin{tabular}{|c|c|c|c|c|c|}
\hline Item & Motivational Factor & f & $\overline{\mathbf{x}}$ & s.s. & Dimension \\
\hline 1 & For the pleasure of discovering new training techniques. & 55 & 5,67 & 1,4 & Intrinsic \\
\hline 2 & For the pleasure it gives me to know more about the sport that I practice. & 55 & 5,56 & 1,63 & Intrinsic \\
\hline 3 & For the pleasure I feel while improving some of my weak points. & 55 & 5,5 & 1,53 & Intrinsic \\
\hline 4 & Because I must do sports to feel good about myself. & 55 & 5,47 & 1,69 & Extrinsic \\
\hline 5 & For the prestige of being an athlete. & 55 & 5,43 & 1,59 & Extrinsic \\
\hline 6 & For the intense emotions that I feel while I am doing a sport that I like. & 55 & 5,34 & 1,84 & Intrinsic \\
\hline 7 & For the excitement I feel when I am really involved in the activity. & 55 & 5,27 & 1,8 & Intrinsic \\
\hline 8 & For the pleasure that I feel while learning training techniques that I have never tried before. & 55 & 5,21 & 1,89 & Intrinsic \\
\hline 9 & For the pleasure of discovering new performance strategies. & 55 & 5,2 & 1,81 & Intrinsic \\
\hline 10 & For the satisfaction I experience while I am perfecting my abilities. & 55 & 5,18 & 1,75 & Intrinsic \\
\hline 11 & For the pleasure I feel in living exciting experiences. & 55 & 5,16 & 1,66 & Intrinsic \\
\hline 12 & Because it is one of the best ways I have chosen to develop other aspects of myself. & 55 & 5,1 & 1,68 & Extrinsic \\
\hline 13 & Because I must do sports regularly. & 55 & 5,07 & 1,81 & Extrinsic \\
\hline 14 & Because I feel a lot of personal satisfaction while mastering certain difficult training techniques. & 55 & 5,05 & 1,73 & Intrinsic \\
\hline 15 & $\begin{array}{l}\text { Because it is a good way to learn lots of things which could be useful to me in other areas of my } \\
\text { life. }\end{array}$ & 55 & 5,03 & 1,67 & Extrinsic \\
\hline 16 & Because it is absolutely necessary to do sports if one wants to be in shape. & 55 & 5 & 1,98 & Extrinsic \\
\hline 17 & For the pleasure I feel while executing certain difficult movements. & 55 & 4,94 & 1,89 & Intrinsic \\
\hline 18 & Because I like the feeling of being totally immersed in the activity. & 55 & 4,89 & 1,85 & Intrinsic \\
\hline 19 & Because it is one of the best ways to maintain good relationships with my friends. & 55 & 4,72 & 2,02 & Extrinsic \\
\hline 20 & To show others how good I am at my sport. & 55 & 4,63 & 2,02 & Extrinsic \\
\hline 21 & Because, in my opinion, it is one of the best ways to meet people. & 55 & 4,61 & 1,89 & Extrinsic \\
\hline 22 & Because I would feel bad if I was not taking time to do it. & 55 & 4,6 & 2,12 & Extrinsic \\
\hline 23 & Because it allows me to be well regarded by people that I know. & 55 & 4,5 & 1,95 & Extrinsic \\
\hline 24 & Because people around me think it is important to be in shape. & 55 & 4,45 & 1,97 & Extrinsic \\
\hline
\end{tabular}

It was determined that the motivation dimensions of the students doing individual sports were mainly related to intrinsic motivation. As for the reasons to do sports, it was primarily important to know more about the sport that one does, to discover new training techniques and to improve abilities.
It was determined that the reasons that motivated the students doing individual sports the least were showing how good one was at the respective sport, sports being the best way to meet people, feeling bad when not doing sports, the importance of being in shape, and being well respected. 
Table 4. Reasons and Motivations of Male Students for Doing Sports

\begin{tabular}{|c|c|c|c|c|c|}
\hline Item & Motivational Factor & f & $\overline{\mathbf{x}}$ & s.s. & Dimension \\
\hline 1 & For the pleasure of discovering new training techniques. & 69 & 5,91 & 1,3 & Intrinsic \\
\hline 2 & For the pleasure it gives me to know more about the sport that I practice. & 69 & 5,81 & 1,46 & Intrinsic \\
\hline 3 & Because I must do sports to feel good about myself. & 69 & 5,73 & 1,54 & Extrinsic \\
\hline 4 & For the prestige of being an athlete. & 69 & 5,71 & 1,39 & Extrinsic \\
\hline 5 & For the satisfaction I experience while I am perfecting my abilities. & 69 & 5,65 & 1,57 & Intrinsic \\
\hline 6 & For the intense emotions that I feel while I am doing a sport that I like. & 69 & 5,6 & 1,63 & Intrinsic \\
\hline 7 & For the pleasure I feel while improving some of my weak points. & 69 & 5,57 & 1,51 & Intrinsic \\
\hline 8 & For the excitement I feel when I am really involved in the activity. & 69 & 5,52 & 1,57 & Intrinsic \\
\hline 9 & For the pleasure of discovering new performance strategies. & 69 & 5,5 & 1,82 & Intrinsic \\
\hline 10 & Because it is a good way to learn lots of things which could be useful to me in other areas of my life. & 69 & 5,44 & 1,5 & Extrinsic \\
\hline 11 & Because it is absolutely necessary to do sports if one wants to be in shape. & 69 & 5,43 & 1,77 & Extrinsic \\
\hline 12 & For the pleasure I feel in living exciting experiences. & 69 & 5,4 & 1,7 & Intrinsic \\
\hline 13 & Because I feel a lot of personal satisfaction while mastering certain difficult training techniques. & 69 & 5,37 & 1,66 & Intrinsic \\
\hline 14 & Because I must do sports regularly. & 69 & 5,36 & 1,67 & Extrinsic \\
\hline 15 & For the pleasure that I feel while learning training techniques that I have never tried before. & 69 & 5,34 & 1,82 & Intrinsic \\
\hline 16 & Because it is one of the best ways I have chosen to develop other aspects of myself. & 69 & 5,27 & 1,51 & Extrinsic \\
\hline 17 & For the pleasure I feel while executing certain difficult movements. & 69 & 5,23 & 1,8 & Intrinsic \\
\hline 18 & Because I like the feeling of being totally immersed in the activity. & 69 & 5,04 & 1,69 & Intrinsic \\
\hline 19 & Because it is one of the best ways to maintain good relationships with my friends. & 69 & 4,85 & 1,93 & Extrinsic \\
\hline 20 & Because, in my opinion, it is one of the best ways to meet people. & 69 & 4,84 & 1,73 & Extrinsic \\
\hline 21 & To show others how good I am at my sport. & 69 & 4,82 & 1,98 & Extrinsic \\
\hline 22 & Because I would feel bad if I was not taking time to do it. & 69 & 4,76 & 2,04 & Extrinsic \\
\hline 23 & Because people around me think it is important to be in shape. & 69 & 4,68 & 1,86 & Extrinsic \\
\hline 24 & Because it allows me to be well regarded by people that I know. & 69 & 4,5 & 1,86 & Extrinsic \\
\hline
\end{tabular}

It was determined that the motivation dimensions of the male students doing sports were mainly related to intrinsic motivation. As for the reasons to do sports, it was primarily important to know more about the sport that one does, to discover new training techniques and to improve abilities.
It was determined that the reasons that motivated the male students doing sports the least were showing how good one was at the respective sport, sports being the best way to meet people, feeling bad when not doing sports, the importance of being in shape, and being well respected. 
Table 5. Reasons and Motivations of Female Students for Doing Sports

\begin{tabular}{|c|c|c|c|c|c|}
\hline Item & Motivational Factor & f & $\overline{\mathbf{x}}$ & s.s. & Dimension \\
\hline 1 & For the pleasure it gives me to know more about the sport that I practice. & 41 & 5,65 & 1,42 & Intrinsic \\
\hline 2 & Because it is one of the best ways I have chosen to develop other aspects of myself. & 41 & 5,6 & 1,37 & Extrinsic \\
\hline 3 & Because I must do sports to feel good about myself. & 41 & 5,58 & 1,58 & Extrinsic \\
\hline 4 & For the pleasure that I feel while learning training techniques that I have never tried before. & 41 & 5,51 & 1,56 & Intrinsic \\
\hline 5 & For the intense emotions that I feel while I am doing a sport that I like. & 41 & 5,43 & 1,7 & Intrinsic \\
\hline 6 & For the pleasure of discovering new training techniques. & 41 & 5,36 & 1,4 & Intrinsic \\
\hline 7 & Because I must do sports regularly. & 41 & 5,34 & 1,62 & Extrinsic \\
\hline 8 & For the pleasure of discovering new performance strategies. & 41 & 5,29 & 1,61 & Intrinsic \\
\hline 9 & For the prestige of being an athlete. & 41 & 5,29 & 1,61 & Extrinsic \\
\hline 10 & Because it is a good way to learn lots of things which could be useful to me in other areas of my life. & 41 & 5,21 & 1,95 & Extrinsic \\
\hline 11 & For the pleasure I feel while improving some of my weak points. & 41 & 5,12 & 1,58 & Intrinsic \\
\hline 12 & Because I feel a lot of personal satisfaction while mastering certain difficult training techniques. & 41 & 5,04 & 1,46 & Intrinsic \\
\hline 13 & For the excitement I feel when I am really involved in the activity. & 41 & 5,02 & 1,79 & Intrinsic \\
\hline 14 & For the satisfaction I experience while I am perfecting my abilities. & 41 & 4,97 & 1,54 & Intrinsic \\
\hline 15 & For the pleasure I feel while executing certain difficult movements. & 41 & 4,92 & 1,69 & Intrinsic \\
\hline 16 & For the pleasure I feel in living exciting experiences. & 41 & 4,78 & 1,62 & Intrinsic \\
\hline 17 & Because I would feel bad if I was not taking time to do it. & 41 & 4,7 & 2,15 & Extrinsic \\
\hline 18 & Because I like the feeling of being totally immersed in the activity. & 41 & 4,63 & 1,71 & Intrinsic \\
\hline 19 & Because it is absolutely necessary to do sports if one wants to be in shape & 41 & 4,6 & 1,9 & Extrinsic \\
\hline 20 & Because it is one of the best ways to maintain good relationships with my friends. & 41 & 4,58 & 1,91 & Extrinsic \\
\hline 21 & Because it allows me to be well regarded by people that I know. & 41 & 4,46 & 2,05 & Extrinsic \\
\hline 22 & Because, in my opinion, it is one of the best ways to meet people. & 41 & 4,34 & 1,62 & Extrinsic \\
\hline 23 & To show others how good I am at my sport. & 41 & 4,26 & 1,91 & Extrinsic \\
\hline 24 & Because people around me think it is important to be in shape. & 41 & 4,21 & 1,78 & Extrinsic \\
\hline
\end{tabular}

It was determined that the motivation dimensions of the female students doing sports were mainly related to intrinsic motivation. As for the reasons to do sports, it was primarily important to know more about the sport that one does, to discover new training techniques and to participate in sports activities that they liked.

It was determined that the reasons that motivated the female students doing sports the least were showing how good one was at the respective sport, sports being the best way to meet people, maintaining good relationship with friends, the importance of being in shape, and being well respected.

\section{Discussion and Conclusions}

Although previous study results support our results, the discussion has been limited due to the small number of previous studies on motivation in sports,

Upon comparing the subscales according to the Sports Motivation Scale (SMS) results of the participants, no difference was found among participants who were performing "Individual Sports or Team Sports" for the scores of "IM-to Know, IM-to Experience Stimulation, Introjection, Identification, and Total Score" $(\mathrm{P}>0,05)$, whereas the difference between the two groups in terms of "Amotivation" was found to be significant $(\mathrm{P}<0,05)$. Cronbach alpha coefficient for the SMS scale was determined to be 0.92 . The reasons that there was difference between the students doing team sports and individual sports in terms of amotivation are: 1) the students cannot reach their goals, 2) they do not know why they do sports, and 3) they have become pessimistic about continuing to do sports.

In previous studies on motivation to participate in sport, it has been determined that the factors such as skill development and learning, entertainment, physical fitness, making friends and achieving are the most important factors affecting the participation in sports (Gill vd., 1983; White and Duda, 1994; Kolt et al., 1999). In this study, similar results are obtained as the reasons for doing sports and the differences in terms of gender variable are 
discussed below.

In this study, it was determined that the reasons for motivation of male and female students attending sports high schools showed similarity; however, intrinsic motivational factors were found to be different. Another difference determined was that the female students found learning useful information more important, while the prestige of being an athlete, discovering new training techniques and the pleasure of mastering their skills were more important for the male students.

Although it was determined that the reasons of motivation of university students depended more on extrinsic factors and that the order of importance for these factors changed in terms of gender, our study showed that the motivational factors showed that there are differences in motivational factors for male and female athletes (Aslan and Dalkıran, 2016). In this study, it was found that the reasons of motivation for sports high school students depended more on the intrinsic motivational factors and that the order of importance of these factors varied according to gender.

In the study by Kılınç et al. (2011) on the motivational levels of athletes, they found that there was no difference according to gender, while Oyar et al. (2001) found that the most important reasons that led male and female students to participation in sports were "improving skills, being healthy physically, learning new skills.” These results showed similarity with those of our study.

It was determined that with regard to the reasons for doing sports, male students attached more importance than female students did to the subscales of "being well respected, gaining prestige, maintaining good relationship with friends", while female students attached more importance to the subscales of "improving other individual aspects, feeling better, learning useful information, feeling intense emotions, feeling bad when not making time for sports."

In the study by Oyar et al. (2001), a significant difference in the subscales of "skill improvement, achievement, entertainment, and activity" for the female students was found, while Çekin et al., (2001) reported that the motivational factors such as being well respected in the social environment and being healthy were prominent. These results showed similarity with our study.

It was determined that the motivational factors of the male students doing sports were mainly related to intrinsic motivation, yet it was also seen that the order of importance of these factors varied according to the gender variable. It was determined that the motivational factors of the female students doing sports were mainly related to intrinsic motivation. However, it was also found that the order of importance of these factors varied in terms of gender.

It was determined that the motivational factors of students doing individual sports were mainly related to intrinsic motivation, while the order of importance of these factors varied according to the individual sport. It was determined that the motivational factors of students doing team sports were mainly related to intrinsic motivation. Besides, it was also found that the order of importance of these factors varied in terms of team sport.

In conclusion, it can be said that both male and female students want to get pleasure from the sports they do and to be successful in their sports. Thus, they are motivated accordingly.

Based on these results, it is recommended that studies should be done to increase the sportive motivation of the students who take sports training. it is recommended to consider the reasons that motivate the students in the planning of sports training.

It is recommended that the emotional factors should be taken into consideration in the motivation of the students who receive sports training. The educational institutions in the sports field are advised to provide professional psychological support in order to encourage students to participate in sports.

\section{REFERENCES}

[1] Aslan C. S. \& Dalkıran O. (2016). "Üniversiteli Sporcuların Spora Güdülenme Nedenlerinin İncelenmesi”, Mehmet Akif Ersoy Üniversitesi Sosyal Bilimler Dergisi, Cilt. 8, Sayı (S424-432)

[2] Brunstein, J. C. (1993). "Personal Goals and Subjective Well-being”. Journal of Personality and Social Psychology, 65: 1061-1070.

[3] Cox, R. H. (1998). "Sport Psychology: Concepts and Applications”. 4 Ed. The McGraw-Hill, p. 236-271.

[4] Cresswell, S., Hodge, K. \& K1dman, L. (2003). "Intrinsic Motivation in Youth Sport: Goal Orientations and Motivational Climate”. Journal of Physical Education New Zealand, 36: 1, 15-26.

[5] Çekin, M. D., Tatar, Y. \& Afyon, Y. A. (2001). “14-16 Yaş Grubunu Spora Teşvik Eden Unsurlar”. Selçuk Üniversitesi, Eğitim Fakültesi Dergisi, Say1.7, Konya.

[6] Gill, D.L., Gross, J. B. \& Huddleston, S. (1983). "Participation Motivation In Young Sports". International Journal of Sport Psychology, cilt.14, 1-14.

[7] Kazak, Z. (2004). "Sporda Güdülenme Ölçeği -SGÖ-‘nin Türk Sporcular İçin Güvenirlik ve Geçerlik Çalışması", Hacettepe Spor Bilimleri Dergisi, Cilt.15, Say1.4.191-206.

[8] Kilınç, M., Ulucan, H., Kaya, K. \& Türkçapar, Ü. (2012). "Takım Sporu Yapanların Motivasyon Düzeylerinin Farklı Değişkenlere Göre İncelenmesi”, Abant İzzet Baysal Üniversitesi Eğitim Fakültesi Dergisi, cilt.11, say1.2:191-206.

[9] Gould, D., Dieffenbach, K.. \& Moffett, A. (2002). Psychological Characteristics and Their Development of Olympic Champions. Journal of Applied Sport Psychology, 14: $172-204$

[10] Hagger, M. S. \& Chatzisarantis, N. L. D. (2007). “Intrinsic 
Motivation and Self Determination in Exercise and Sport”. Human Kinetics.

[11] İkizler, H. C. \& Karagözoğlu, C. (1996). “Sporda Başarının Psikolojisi”. Alfa Basım Yayım Dağıtım, İstanbul.

[12] Kolt, G., Kirby, R., Bar-Eli, M., Blumenstein, B., Chadha, N. K., Liu, J. \& Kerr, G. (1999), “A Cross-cultural Investigation of Reasons for Participation in Gymnastics”, International Journal of Sport Psychology, 30, 381-398.

[13] Murcia, J. A. M., Gimeno, E. C. \& Coll, D. G. C. (2008). "Relationships among Goal Orientations, Motivational Climate and Flow in Adolescent Athletes: Differences by Gender”. The Spanish Journal of Psychology, 11: 1, 181-191.

[14] Nicholls, J. G. (1984). "Achievement Motivation: Concepts of Ability, Subjective Experience, Task Choice and Performance”. Psychological Review, 91: 329-346.

[15] Nicholls, J. G. (1992). "The General And The Specific in The Development and Expression of Achievement Motivation”. in G. C. Roberts (Ed.), Motivation in Sport and Exercise, Champaign, IL: Human Kinetics, p. 31-56.

[16] Oyar, Z. B., Aşçı, F. H., Çelebi, M. \&- Mülazımoğlu, Ö.(2001), "Spora Katılım Güdüsü Ölçeğinin Geçerlik ve Güvenirlik Çalışması”. Hacettepe Spor Bilimleri Dergisi, cilt.12, say1.2: 21-32.

[17] Roberts, G. C., Treasure, D. C. \& Conroy, D. E. (2007). "Understanding the Dynamics of Motivation in Sport and Physical Activity: An Achievement Goal Interpretation”. In G. Tenenbaum \& R. C. Eklund (Ed.), Handbook of Sport Psychology, Third Edition, John Wiley \& Sons, p. 3-10.

[18] Pelletier, Luc G. - Fortier, Michelle S. - Vallerant, Robert J. - Tuson, Kim M. - Briere, Nathalie M. \& Blais, Marc R. (1995), "Toward A New Measure Of Intrinsic Motivation, Extrinsic Motivation and Amotivation in Sport: The Sport Motivation Scale (SMS)", Journal of Sport and Exercise Psychology, 17(2), 35-53.

[19] Soyer, F., Can, Y., Güven, H., Hergüner, G., Bayansalduz, M. \& Tetik, B. (2010), "Sporculardaki Başarı Motivasyonu İle Takım Birlikteliği Arasındaki İlişkinin İncelenmesi”, Uluslararası İnsan Bilimleri Dergisi, cilt.7, sayı.1: 225-239).

[20] Sage, G. H. (1984). “Introduction to Motor Behavior”. 3. Ed. Reading. 29, 723-735.

[21] Singer, R. N., Hausenblas, H. A. \& Janelle, C. (2001). "Self-Efficacy Beliefs of Athletes, Teams, and Coaches". Handbook of Sport Psychology, 2: 240-361. New York: John Wiley and Sons.

[22] Toros, T. \& Yetim, Ü. (2000). "Sporda Algilanan Motivasyonel (Güdüsel) İklim Ölçeğinin Türk Sporcuları İçin Uyarlama Ön Çalışması. Uluslararası Spor Bilimleri Kongresi. 11-13 Mayıs, İstanbul.

[23] Tanrı̈öğen, A. (2011). "Bilimsel Araştırma Yöntemleri”. Anı Yayınc1lık, Ankara.

[24] Tiryaki, Ş. (2000). "Spor Psikolojisi: Kavramlar, Kuramlar ve Uygulama”. Ankara: Eylül Kitap ve Yayınevi.

[25] Yeltepe, H. (2007). “Spor ve Egzersiz Psikolojisi”. Epsilon Yayınc1lik.
[26] White, A. S. \& Duda, L. J. (1994). "The Relationship of Gender, Level of Sport Involvement, and Participation Motivation to Task and Ego Orientation”. International Journal of Sport Psychology, 25, 40-48. 